\title{
Migraine polygenic risk score associates with efficacy of migraine-specific drugs
}

Lisette J.A. Kogelman, PhD, Ann-Louise Esserlind, MD, PhD, Anne Francke Christensen, MD, PhD, Swapnil Awasthi, MSc, Stephan Ripke, PhD, Andres Ingason, PhD, Olafur B. Davidsson, MSc, Christian Erikstrup, PhD, Henrik Hjalgrim, PhD, DMSc, Henrik Ullum, PhD, Jes Olesen, DMSc, and Thomas Folkmann Hansen, PhD, DBDS Genomic Consortium, The International Headache Genetics Consortium

Neurol Genet 2019;5:e364. doi:10.1212/NXG.0000000000000364

\section{Abstract}

\section{Objective}

To assess whether the polygenic risk score (PRS) for migraine is associated with acute and/or prophylactic migraine treatment response.

\section{Methods}

We interviewed 2,219 unrelated patients at the Danish Headache Center using a semistructured interview to diagnose migraine and assess acute and prophylactic drug response. All patients were genotyped. A PRS was calculated with the linkage disequilibrium pred algorithm using summary statistics from the most recent migraine genome-wide association study comprising $\sim 375,000$ cases and controls. The PRS was scaled to a unit corresponding to a twofold increase in migraine risk, using 929 unrelated Danish controls as reference. The association of the PRS with treatment response was assessed by logistic regression, and the predictive power of the model by area under the curve using a case-control design with treatment response as outcome.

\section{Results}

A twofold increase in migraine risk associates with positive response to migraine-specific acute treatment (odds ratio $[\mathrm{OR}]=1.25[95 \%$ confidence interval $(\mathrm{CI})=1.05-1.49]$ ). The association between migraine risk and migraine-specific acute treatment was replicated in an independent cohort consisting of 5,616 triptan users with prescription history ( $\mathrm{OR}=3.20$ $[95 \% \mathrm{CI}=1.26-8.14])$. No association was found for acute treatment with non-migrainespecific weak analgesics and prophylactic treatment response.

\section{Conclusions}

The migraine PRS can significantly identify subgroups of patients with a higher-than-average likelihood of a positive response to triptans, which provides a first step toward genetics-based precision medicine in migraine.
Correspondence

Dr. Folkmann Hansen

Thomas.hansen@regionh.dk

\section{RELATED ARTICLE}

\section{Editorial}

Headaches and polygenic scores

Page e368 


\section{Glossary}

ACE = angiotensin-converting enzyme; $\mathbf{A U C}=$ area under the curve; $\mathbf{C I}=$ confidence interval; $\mathbf{D B D S}=$ Danish Blood Donor Study; GWAS = genome-wide association study; HET = heterozygosity; IHGC = International Headache Genetics Consortium; $\mathbf{L D}=$ linkage disequilibrium; $\mathbf{M A}=$ migraine with aura; $\mathbf{M O}=$ migraine without aura; $\mathbf{O R}=$ odds ratio; $\mathbf{P C}=$ principal component; $\mathbf{P R S}$ = polygenic risk score; $\mathbf{S N P}$ = single nucleotide polymorphism.

For complex diseases, there is an expected interindividual variation in the response to pharmacologic treatment. The current trend in medical science focuses on precision medicine, tailoring treatments to subsets of patients. Treatment can be improved by considering individual genomic prediction relating to drug metabolism. ${ }^{1,2}$ Genome-wide association studies (GWASs) have been used in many complex diseases to detect genetic variants associated with diseases, and subsequently to generate polygenic risk scores (PRSs), which includes the additive effect of all variants of the disease. To date, PRS analysis is gaining ground in disease risk prediction, ${ }^{3}$ identifying and quantifying comorbidities and endophenotypes, ${ }^{4}$ and drug responses. ${ }^{5,6}$

Migraine is a polygenic disorder with an estimated heritability of $40 \%-60 \%{ }^{7-9}$ and a worldwide prevalence of $18 \%{ }^{10}$ The acute treatment of migraine is dominated by the highly receptor-specific triptans. Approximately $25 \%$ of patients with migraine do not respond to triptans. In case of a high frequency of migraine attacks, many different nonspecific prophylactic drugs may be prescribed. It is unknown to what degree this variation in treatment response is related to genetic variants. ${ }^{11}$

We aim to test whether the genetic burden of migraine risk variants, defined by a PRS derived from the recent metaanalysis on migraine, ${ }^{12}$ is associated with acute and prophylactic migraine treatment.

\section{Methods}

\section{Study population-the target sample}

The study population consisted of 2,591 patients with migraine who were recruited at the Danish Headache Center in 1999-2002, 2005-2006, and 2010-2011. ${ }^{13,14}$ All patients with migraine were interviewed face to face or by telephone by a trained physician or trained senior medical student using a semistructured interview. The interview was designed by head of classification committee Prof. Jes Olesen to phenotype and classify migraine diagnosis according to the International Classification of Headache Disorders, second edition. ${ }^{15}$

\section{Migraine drug response}

The semistructured interview included questions covering the necessary clinical data for migraine diagnoses and information on the effect of migraine treatment. Acute treatment effect was considered to be positive in cases where the patient reported at least $50 \%$ pain reduction within 2 hours after taking medication. Prophylactic treatment effect was considered to be positive in cases where the patient reported a reduction of over $50 \%$ in migraine attacks. For acute treatment, the patient was asked about efficiency of (1) triptans and (2) ergotamine, which are both migraine-specific drugs, and (3) weak analgesics, which is nonspecific for migraine treatment. For prophylactic treatment, the patient was asked about the efficiency of (1) $\beta$-blockers, (2) $\mathrm{Ca}^{2+}$ antagonists, (3) angiotensin II receptor blockers, (4) angiotensin-converting enzyme (ACE) inhibitors, (5) anticonvulsants, (6) antidepressants, and (7) hormone treatment. Both generic and commercial names were mentioned, where the interviewer used promedicin.dk as reference. The questioned drug needed to be taken specifically for treatment of migraine. For all questions, the answer "Do not know" was considered as missing data.

\section{Genotyping}

All patients with migraine were genotyped on the Illumina HumanOmniExpress $12 \mathrm{vl}(\mathrm{n}=2,152)$ or Illumina HumanOmniExpress 24v1 $(n=439)$ chip. For each data set, the quality control of genotypes was performed using PLINK 1.9. ${ }^{16}$ We used genotypes for 2,766 ethnicity-sensitive single nucleotide polymorphisms (SNPs) common to all Illumina SNP arrays to estimate European, Asian, and African ancestry probabilities with STRUCTURE ${ }^{17}$ and excluded individuals with $<90 \%$ European ancestry. SNPs with $<0.95$ genotyping rate, $<0.01$ minor allele frequency, or $p<1 \times 10^{-6}$ for HardyWeinberg Equilibrium were excluded, and individuals with $<0.98$ genotype rate were removed. Next, we created a subset of markers independent of each other with respect to linkage disequilibrium (LD) using a window size of 100 markers shifting by 25 markers at a time and removed 1 half of every SNP pair with genotypic $r^{2}>0.1$. This was performed to avoid overestimating the effect by including mutually dependent SNPs, i.e., SNPs in LD. Using this subset of markers, we calculated heterozygosity (HET) and sex and removed (1) all individuals with outlying HET values ( $>5 \mathrm{SD}$ from the median of the whole sample) and (2) all individuals where sex determined from genotype did not match reported sex. We then removed all $\mathrm{A} / \mathrm{T}$ and $\mathrm{C} / \mathrm{G}$ markers to avoid strand issues. Related individuals were detected based on their genotype data, and 1 random individual per related couple (Pihat $>0.10$ ) was removed. After filtering and quality control, 542,168 SNPs and 2,219 individuals were retained for analyses. The total data set of 2,219 patients with migraine consisted of 1,201 patients who had migraine without aura (MO) and 1,018 patients who had migraine with aura (MA). Cases with probable migraine (with or without aura) were included in the analysis, and in case the individual had both $\mathrm{MA}$ and $\mathrm{MO}$, they were assigned to the MA subgroup. 


\section{PRS calculation}

The PRS was calculated using LDpred, which adjusts for LD between markers and further rescales allelic effects based on the likelihood of each marker belonging to the fraction of markers assumed to be causal. ${ }^{18}$ We calculated PRSs using the default models for causal variant fraction in LDpred (i.e., 1 , $0.3,0.1,0.03,0.01,0.003$, and 0.001). The LD information was retrieved from the subjects with migraine and 929 unrelated Danish controls, who were genotyped on the same genotype chip (Illumina HumanOmniExpress 12v1). To calculate PRSs for migraine, we used $p$ values and $\log _{10}$ odds ratios (ORs) from a subset of the International Headache Genetics Consortium (IHGC) migraine GWAS meta-analysis $\left(\mathrm{n}_{\text {case }}=59,674 ; \mathrm{n}_{\text {control }}=316,078\right)^{12}$ from which all individuals of Danish origin (1,771 cases and 1,000 controls) had been removed to avoid overlap between the discovery and target sample and a resulting overestimation of allelic effects.

To investigate which fraction of causal variants gives the best prediction of migraine, we compared the PRSs of our migraine sample $(n=2,219)$ with the 929 Danish controls. Migraine was most significantly predicted with a model assuming the fraction of causal variants to be $0.03(p=6.91 \times$ $\left.10^{-27}\right)$. The PRS generated under this model predicted both MO and MA significantly $\left(p=3.69 \times 10^{-26}\right.$ and $\left.4.98 \times 10^{-17}\right)$. Next, we investigated whether the PRSs of the migraine subtypes could predict the respective subtype better than the PRS of migraine, using the GWAS on the clinical subset (5,557 MA and 7,352 MO) of the IHGC meta-analysis. ${ }^{13}$ This was not the case, likely because of the limited sample size of the discovery cohort; the PRS of MO was predicted with a $p$ value of $2.70 \times 10^{-12}$ and the PRS of MA predicted MA with a $p$ value of $1.61 \times 10^{-3}$. Therefore, all analyses were conducted using the PRS of migraine. We then rescaled the migraine PRS to a mean of zero and a unit corresponding to a twofold genetic increased risk for migraine in the target population; this was done by first subtracting the mean PRS from each subject's PRS and then multiplying it by $\log (\mathrm{OR}) /$ $\log (2)$, where the OR was extracted from the model predicting migraine using the 2,219 cases and 929 controls.

\section{Statistical analysis}

The rescaled PRS for migraine was tested for its association with drug response using a logistic regression model including age, sex, genotype chip, and the first 10 principal components (PCs) of the genotypes as covariates. The PCs were calculated in PLINK ${ }^{16}$ and included in the model to correct for population stratification. As triptan and ergotamine are both migrainespecific drugs used for acute treatment and act through the same serotonin receptors $\left(5-\mathrm{HT}_{1 \mathrm{~B}}\right.$ and $\left.5-\mathrm{HT}_{1 \mathrm{D}}\right)$, they were analyzed together to increase the statistical power. The mode of action of prophylactic treatments is unknown; therefore, they were analyzed together. The association of migraine-specific acute, migraine nonspecific acute, and prophylactic treatment with the PRS was corrected for multiple testing $(\mathrm{n}=3)$ using Bonferroni correction resulting in adjusted $p$ values $\left(p_{\text {adj }}\right)$. As prophylactic treatment is potentially confounded by comorbid hypertension or epilepsy, we tested whether these comorbidities had a significant effect on treatment response. In case they were statistically significantly associated with treatment response, they were included as covariates.

All analyses were performed for the complete set of patients with migraine. Subsequently, it was tested whether there was a statistically significant difference between the migraine subtypes by including an interaction term between the PRS and migraine subtype. We presented the area under the curve (AUC), representing the prediction accuracy and ORs, using the partial Receiver Operating Caracteristic R-package. ${ }^{19}$ The AUC was calculated for both the model including only the covariates and the full model including the PRS and the covariates. The difference between the 2 AUCs was tested using the DeLong test in the partial Receiver Operating Caracteristic R-package. ORs were presented with $95 \%$ confidence intervals (CIs). All analyses were performed in R (version 3.4.3.). ${ }^{20}$

\section{Replication cohort}

The Danish Blood Donor Study (DBDS) genomic cohort $(n=79,595)$ was used as the replication cohort (see detailed description elsewhere). ${ }^{21}$ The PRS for migraine was calculated as done for the clinical cohort. Using a subpopulation of the DBDS genomic cohort $(n=17,222)$ with information on selfreported migraine ( $\left.\mathrm{n}_{\text {migraine }}=3,906\right)$, we estimated the OR for migraine within the DBDS genomic cohort $(\mathrm{OR}=3.98,95 \%$ $\mathrm{CI}=3.18-4.98$ ). The OR for migraine was used for subsequent normalization of the PRS as done for the clinical cohort. Using the prescription register of the 79,595 participants, we identified 5,616 users of migraine-specific treatment (1,372 males and 4,244 females). Positive triptan responders were defined as having 10 or more purchases of triptans, as previously suggested to be a reliable indicator of positive treatment response. $^{22}$ This resulted in 1,246 triptan responders (213 males and 1,033 females). In the regression model, age, sex, and the 10 first PCs were included as covariates.

\section{Standard protocol approval, registrations, and patient consents}

Written informed consent was obtained from all participants. The study was approved by the Danish Ethical Standards Committee (H-2-2010-122) and the Danish Data Protection Agency (01080/GLO-2010-10).

\section{Data availability}

Summary statistics of the GWAS are available upon agreement with the IHGC due to embargo with 23andMe. Genotype data of our clinical cohort are available upon agreement with the senior author and upon material transfer agreement.

\section{Results}

\section{Sample characteristics}

Our data set consists of 2,219 patients with migraine including $1,201 \mathrm{MO}$ and 1,018 MA patients. The male:female ratio in patients with migraine was $1: 4.7$; this was slightly lower in 
MO (1:5.8) than in MA $(1: 3.8)\left(p=2.7 \times 10^{-4}\right)$. The patients with migraine were on average 44.2 years old with an SD of 12.8. There was no significant difference in age (SD) between MO and MA (44.0 [12.1] years and 44.4 [13.6] years, respectively). A higher response rate was found for MO than MA in acute and prophylactic treatment response (table 1). The difference in response rates implies a potential difference in association with the PRS across migraine subtypes, and therefore, we tested whether such difference was evident. There was a significantly higher response rate for female patients with migraine than male patients with migraine for acute treatment $(p=0.03)$. Furthermore, among the responders to prophylactic treatment, there were a higher number of patients with migraine with hypertension (table 2).

\section{Association with acute treatment response}

Acute treatment response was assessed by 2 different classes of drugs: migraine-specific and nonspecific drugs (figure 1). The PRS was statistically significantly associated with positive migraine-specific acute treatment response: a unit increase in the PRS (corresponding to a twofold increased migraine risk) was associated with an OR of $1.25\left(95 \% \mathrm{CI}=1.05-1.49, p_{\text {adj }}=\right.$ $\left.1.25 \times 10^{-2}\right)$. Although the PRS was statistically significantly associated with acute treatment response, there was no statistically significant improvement of the accuracy when added to a model that included treatment covariates $(p=0.50)$ : the AUC for the full model was 0.603 (95\% CI $=0.569-0.637$ ), and the model including all covariates except the PRS was 0.598 (95\% CI $=0.563-0.633)$. No statistically significant interaction was present between the PRS and migraine subtypes, age, or sex. However, testing the association of acute treatment response with genetic load for each sex separately showed a strong signal for males $(\mathrm{OR}=2.17$ [1.36-3.57], $\left.p=1.55 \times 10^{-3}\right)$ but not for females $(\mathrm{OR}=1.15[0.95-1.39]$, $p=0.16)$.

To ensure that the signal we are detecting is between migraine-specific drugs and the genetic load of migraine, we used migraine nonspecific drugs (weak analgesics) as negative control and saw no significant association. As a secondary analysis, we split the migraine-specific drugs into triptans and ergotamine; we saw only a statistically significant association for triptans $\left(\mathrm{OR}=1.27[1.07-1.51], p=7.60 \times 10^{-3}\right)$. The stronger signal between the PRS and treatment response among males was still present among triptan response $(\mathrm{OR}=$ $\left.2.08[1.31-3.39], p=2.43 \times 10^{-3}\right)$ and not for females (OR $=$ 1.17 [0.97-1.42], $p=0.10$ ).

\section{Association with prophylactic treatment response}

Migraine can be preventively treated with $\beta$-blockers, calcium antagonists, angiotensin II receptor antagonists, ACE inhibitors, antiepileptics, antidepressants, and by hormone treatment. Because their mode of action on migraine is unknown, we analyzed all prophylactic treatments together (figure 2 ). We did not find a statistically significant association between the migraine PRS and a positive prophylactic treatment response: a unit increase in the PRS (corresponding to a twofold increased migraine risk) resulted in an OR of $1.07(95 \% \mathrm{CI}=0.90-1.27)$.

Table 1 Response rates of the investigated acute and prophylactic drugs in all patients with migraine, patients with migraine without aura, and patients with migraine with aura

\begin{tabular}{|c|c|c|c|c|c|c|}
\hline & \multicolumn{3}{|c|}{$\%$ (Total number of patients) } & \multicolumn{3}{|c|}{ Migraine without vs with aura } \\
\hline & Migraine & MO & MA & OR & $95 \% \mathrm{Cl}$ & $p$ Value \\
\hline Acute treatment response $^{a}$ & $81.5(1,840)$ & $87.0(1,116)$ & $73.1(724)$ & 0.41 & $0.32-0.51$ & $5.29 \times 10^{-14}$ \\
\hline Triptan & $80.9(1,828)$ & $86.6(1,113)$ & $72.0(715)$ & 0.40 & $0.31-0.50$ & $9.99 \times 10^{-15}$ \\
\hline Ergotamine & $40.0(255)$ & $43.1(102)$ & 37.9 (153) & 0.80 & $0.48-1.34$ & 0.40 \\
\hline Weak analgesics & $27.6(1,626)$ & $21.2(848)$ & $34.5(778)$ & 1.92 & $1.56-2.43$ & $2.54 \times 10^{-9}$ \\
\hline Prophylactic treatment response $^{b}$ & $54.2(1,106)$ & $53.8(651)$ & $55.0(455)$ & 1.05 & $0.82-1.33$ & 0.70 \\
\hline$\beta$-blocker & $29.9(782)$ & $30.0(460)$ & $29.8(322)$ & 0.99 & $0.73-1.35$ & 0.96 \\
\hline Ca2+ antagonist & $15.9(201)$ & $15.4(117)$ & $16.7(84)$ & 1.10 & $0.51-2.36$ & 0.81 \\
\hline Ang. II receptor antagonist & $41.2(580)$ & $42.2(358)$ & $39.6(222)$ & 0.90 & $0.64-1.27$ & 0.55 \\
\hline ACE inhibitors & $25.5(102)$ & $26.8(56)$ & $23.9(46)$ & 0.86 & $0.35-2.11$ & 0.74 \\
\hline Anticonvulsants & $27.9(495)$ & $25.9(293)$ & $30.7(202)$ & 1.26 & $0.85-1.88$ & 0.25 \\
\hline Antidepressants & $24.3(136)$ & $18.1(83)$ & $34.0(53)$ & 2.33 & $1.05-5.17$ & 0.04 \\
\hline Hormone treatment & $37.0(81)$ & $37.8(45)$ & $36.1(36)$ & 0.93 & $0.38-2.31$ & 0.88 \\
\hline
\end{tabular}

Abbreviations: $\mathrm{ACE}=$ angiotensin-converting enzyme; Ang. II receptor antagonist = angiotensin II receptor antagonist; $\mathrm{Cl}=$ confidence interval; $\mathrm{MA}=$ migraine with aura; $\mathrm{MO}=$ migraine without aura; OR = odds ratio.

Presented ORs and $p$ values are for MO vs MA, with MO as the reference level for presented ORs.

${ }^{a}$ Acute treatment response only includes triptans and ergotamine (both 5-HT $1 \mathrm{~B} / \mathrm{D}$ receptor antagonists).

b Prophylactic treatment response includes all medications questioned. 
Table 2 Descriptive statistics of potential confounding factors

\begin{tabular}{|c|c|c|c|c|c|}
\hline & Nonresponders & Responders & OR & $95 \% \mathrm{Cl}$ & $p$ Value \\
\hline \multicolumn{6}{|l|}{ Acute treatment } \\
\hline Age (mean [SD]) & $41.71(13.09)$ & $44.87(12.05)$ & $-3.16^{a}$ & -3.53 to -2.79 & $5.28 \times 10^{-5}$ \\
\hline Sex (M: F ratio) & $1: 4.31$ & $1: 6.11$ & 1.42 & 1.04 to 1.93 & 0.03 \\
\hline Migraine subtype (\% MO) & 42.65 & 64.73 & 2.47 & 1.94 to 3.14 & $5.3 \times 10^{-14}$ \\
\hline Epilepsy (\%) & 3.62 & 2.74 & 0.75 & 0.38 to 1.50 & 0.42 \\
\hline Hypertension (\%) & 15.00 & 17.69 & 1.22 & 0.88 to 1.69 & 0.24 \\
\hline \multicolumn{6}{|l|}{ Prophylactic treatment } \\
\hline Age (mean [SD]) & $43.49(13.27)$ & $45.17(12.15)$ & $-1.68^{a}$ & -2.03 to -1.33 & 0.03 \\
\hline Sex (M: F ratio) & $1: 4.82$ & $1: 5.82$ & 1.21 & 0.87 to 1.67 & 0.25 \\
\hline Migraine subtype (\% MO) & 59.49 & 58.33 & 0.95 & 0.75 to 1.21 & 0.70 \\
\hline Epilepsy (\%) & 2.96 & 3.17 & 1.07 & 0.54 to 2.13 & 0.85 \\
\hline Hypertension (\%) & 15.61 & 23.04 & 1.60 & 1.19 to 2.20 & $1.97 \times 10^{-3}$ \\
\hline
\end{tabular}

Abbreviations: $\mathrm{Cl}=$ confidence interval; $\mathrm{MO}=$ migraine without aura; $\mathrm{OR}=$ odds ratio.

${ }^{\text {a }}$ As this is a continuous variable, we showed the difference in age between nonresponders and responders, instead of an OR.

For all ORs the nonresponders are used as reference.

Again, we did not see any statistically significant interaction between the PRS and migraine subtypes.

To test whether treatment of comorbidities was masking the association between the PRS and treatment response, we tested each drug separately. Comorbid hypertension was statistically significantly associated with angiotensin II receptor blockers and ACE inhibitors $\left(p=2.85 \times 10^{-4}\right.$ and 4.51 $\times 10^{-2}$, respectively), and epilepsy was statistically significantly associated with anticonvulsants $\left(p=8.88 \times 10^{-3}\right)$. We found no statistically significant associations between any prophylactic treatment response and the PRS, although it should be noted that prophylactic treatments were used only by a relatively small proportion of the patients.

\section{Replication of the association with triptan response}

As it has been shown that pharmacy databases are a valuable source to identify treatment responders, we used the DBDS Genomic Cohort to replicate the association between genetic load of migraine and triptan response. We found a statistically significant association between the PRS of migraine and triptan response with an OR of 1.78 (95\% CI $=1.20-2.64$, $\left.p=3.36 \times 10^{-2}\right)$. We found an association for both males and females $(\mathrm{OR}=3.20$ [1.26-8.14] and 1.63 [1.05-2.53], respectively). Although the OR was higher for males, the difference was not statistically significant. The prediction showed an increased rate of triptan response among the individuals with higher genetic load for migraine (figure 3 ).

\section{Discussion}

We show that the genetic burden of migraine is associated with the response to pharmacologic treatment. The PRS for migraine was statistically significantly associated with response to migraine-specific treatment: triptans and/or ergotamine. Neither the response to weak analgesics nor the response to prophylactic treatment, which are not migraine specific, was associated with the PRS.

Figure 1 Association of the polygenic risk score with acute treatment response

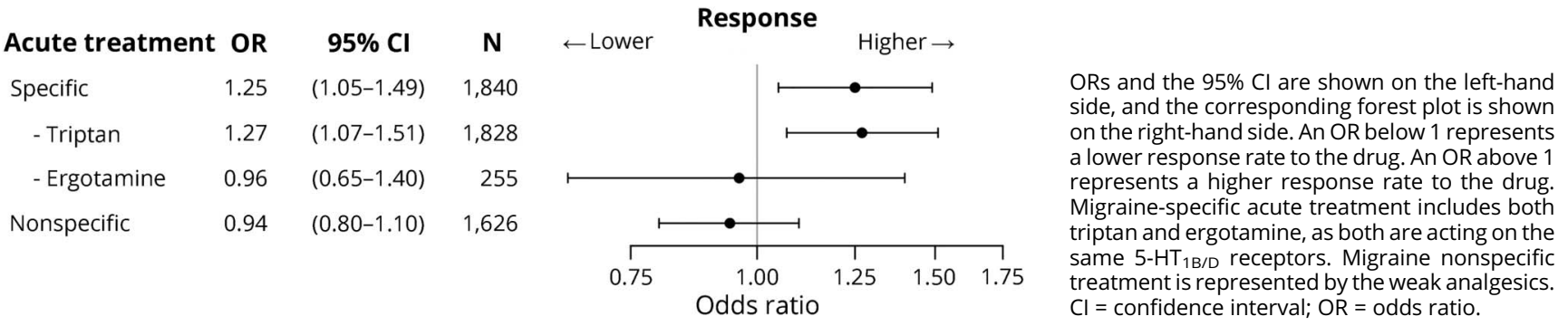




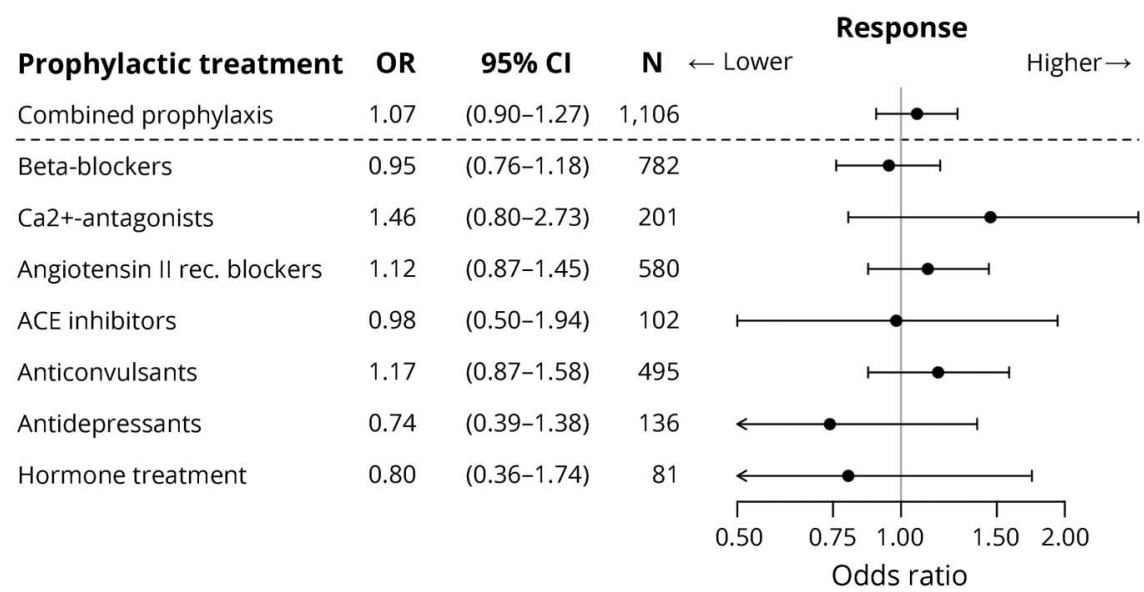

ORs and the $95 \% \mathrm{Cl}$ are shown on the left-hand side, and the corresponding forest plot is shown on the right-hand side. An OR below 1 represents a lower response rate to the drug. An OR above 1 represents a higher response rate to the drug. Acute treatment includes both triptan and ergotamine, as both are acting on the same $5-\mathrm{HT}_{1 \mathrm{~B} /}$ $\mathrm{D}$ receptors. Prophylactic treatment response includes all questioned treatments summed up (positive response to any prophylactic drug vs response to none). $\mathrm{ACE}=$ angiotensin-converting enzyme; $\mathrm{Cl}=$ confidence interval; $\mathrm{OR}=$ odds ratio.
Genomics play an important role in the variability of drug response, which is best understood in relation to pharmacokinetics. ${ }^{23,24}$ Recently, PRS studies have predicted drug response in psychiatric diseases. A PRS of major depressive disorder explained $1.2 \%$ of the antidepressant response. ${ }^{25}$ In schizophrenia, no statistically significant association was found between the response to clozapine and PRS of schizophrenia, although not significant. ${ }^{26}$ The PRS could not predict treatment-resistant schizophrenia, ${ }^{6}$ but a lower PRS for schizophrenia was associated with a positive response to lithium in bipolar affective disorder. ${ }^{5}$ A better understanding of the genetic contribution in migraine drug response could pave the road to personalized treatment of migraine or deepen our understanding of the underlying pathophysiology. Recently, a PRS of migraine has been associated with migraine $(\mathrm{OR}=1.76)$, migraine subtypes (OR MO = 1.57; OR MA = 1.85), and severity of migraine $(\mathrm{OR}=1.29) .{ }^{27}$ Although information about

Figure 3 Replication of the association of the polygenic risk score (PRS) with acute treatment response

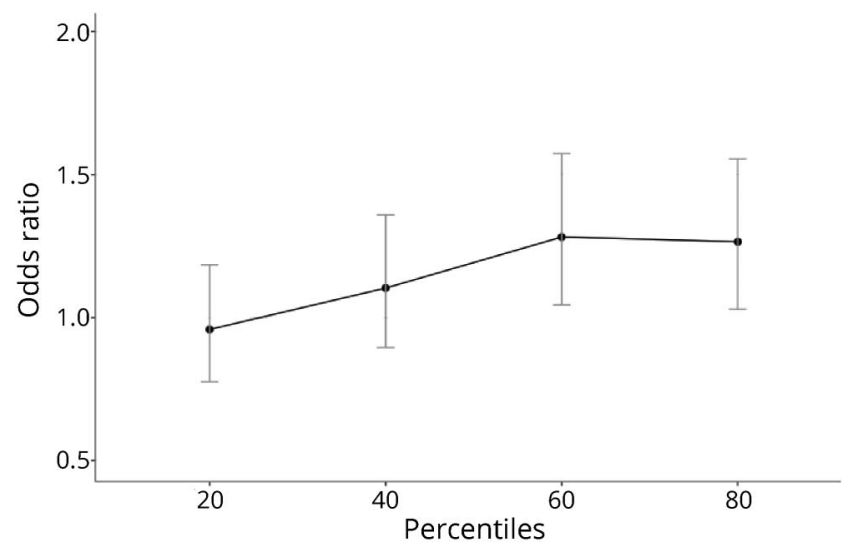

Odds ratio by PRS within each 20 percentiles for $n=5,616$ triptan users in the Danish Blood Donor Study replication cohort. migraine treatment response was not available in their cohort, they report a higher PRS among individuals who had selfreported use of triptans $(\mathrm{OR}=1.12)$.

Previously, the association between the cumulative genetic risk score, based on the count of number of risk alleles of 12 migraine-associated SNPs, and migraine drug response was investigated. ${ }^{14}$ The OR was 1.09 (95\% CI $\left.=1.03-1.15\right)$ for acute treatment response, but no significant correlation of the cumulative genetic risk score with prophylactic treatment was found. In the current study, we found higher estimates than previously for acute treatment response. This may be a consequence of increased sample size in the discovery sample resulting in improved accuracy of the effect size of the genetic variants. Furthermore, the cumulative genetic risk score previously used is not comparable with this study, as we used a weighted risk score and included all genotyped SNPs.

Treatment response shows, for migraine as well as other conditions, a large inter-individual variation and, therefore, a precise measurement of positive treatment response is not easily defined. Many factors may affect treatment response, e.g., polypharmacy, comorbidity, and body mass index. To obtain enough power, we have analyzed the different drugs collectively, which may not be optimal, as a patient may not have tried all drugs questioned and, therefore, may be incorrectly defined as a nonresponder. Furthermore, although we used a semistructured interview, recall bias and negativity bias are inherent limitations. Our PRS is based on the effect sizes of common SNPs that explain an estimated $14.63 \%$ of the overall of the migraine phenotype. ${ }^{12}$ Patients with migraine with a low PRS might nevertheless have a high genetic burden if they carry rare genetic variants with relatively high effect estimates. On the other hand, a high genetic burden of migraine may be associated with specific symptoms of migraine or, for example, severity of migraine. Patients in this study were recruited from the Danish Headache Center, which is a tertiary referral center. Patients therefore have 
a relatively severe migraine. In other diseases, genes in the monoamine oxidase (MAO) A and cytochrome P450 superfamily are associated with drug response, ${ }^{2,28}$ showing the genetic contribution of drug metabolic pathways. There is no evidence that those genes are interacting with migraineassociated genes, and therefore, those are not represented by the PRS. Future and larger studies may focus on other models, such as Bayesian methods extensively used in plant and animal breeding, and/or they may include epistatic interaction effects that potentially have a higher predictive power to predict the genetic risk score of patients with migraine.

While currently the effect size is too small to be clinically important, the study provides an important proof of concept. Furthermore, we were able to replicate the association in an independent cohort of Danish blood donors, although the response phenotype is affected by noise (sensitivity of $82 \%$ and a specificity of $66 \%$ ). We expect that we will see increased predictive power with an increased sample size in the migraine GWAS and/or a future GWAS focusing on migraine treatment response. Thus, future studies might enable us to define more homogeneous groups of patients benefitting from specific treatments using genetic data. With the arrival of new migraine treatments, such as the novel but expensive calcitonin generelated peptide antibodies, a genetic classifier to identify patients who are likely to benefit from the treatment could have great clinical impact.

\section{Acknowledgment}

The authors thank all participating patients and the employees at the Danish Headache Center for their help during the recruitment of the patients.

\section{Study funding}

This project was financed by a grant from Candys Foundation “CEHEAD” (Prof. Jes Olesen).

\section{Disclosure}

Disclosures available: Neurology.org/NG.

\section{Publication history}

Received by Neurology: Genetics March 21, 2019. Accepted in final form September 4, 2019.

Appendix 1 Authors

\begin{tabular}{|c|c|c|c|}
\hline Name & Location & Role & Contribution \\
\hline $\begin{array}{l}\text { Lisette J.A. } \\
\text { Kogelman, } \\
\text { PhD }\end{array}$ & $\begin{array}{l}\text { Rigshospitalet Glostrup, } \\
\text { Denmark }\end{array}$ & Author & $\begin{array}{l}\text { Conception and } \\
\text { design of the } \\
\text { study; acquisition } \\
\text { and analysis of } \\
\text { data; and drafting } \\
\text { a significant } \\
\text { portion of the } \\
\text { manuscript or } \\
\text { figures }\end{array}$ \\
\hline $\begin{array}{l}\text { Ann-Louise } \\
\text { Esserlind, MD, } \\
\text { PhD }\end{array}$ & $\begin{array}{l}\text { Rigshospitalet Glostrup, } \\
\text { Denmark }\end{array}$ & Author & $\begin{array}{l}\text { Acquisition and } \\
\text { analysis of data }\end{array}$ \\
\hline
\end{tabular}

Appendix 1 (continued)

\begin{tabular}{|c|c|c|c|}
\hline Name & Location & Role & Contribution \\
\hline $\begin{array}{l}\text { Anne Francke } \\
\text { Christensen, } \\
\text { MD, PhD }\end{array}$ & $\begin{array}{l}\text { Rigshospitalet Glostrup, } \\
\text { Denmark }\end{array}$ & Author & $\begin{array}{l}\text { Acquisition and } \\
\text { analysis of data }\end{array}$ \\
\hline $\begin{array}{l}\text { Swapnil } \\
\text { Awasthi, MSc }\end{array}$ & $\begin{array}{l}\text { Charité-Universitätsmedizin, } \\
\text { Berlin, Germany }\end{array}$ & Author & $\begin{array}{l}\text { Acquisition } \\
\text { and analysis of } \\
\text { data }\end{array}$ \\
\hline $\begin{array}{l}\text { Stephan } \\
\text { Ripke, PhD }\end{array}$ & $\begin{array}{l}\text { Charité-Universitätsmedizin, } \\
\text { Berlin, Germany; } \\
\text { Massachusetts General } \\
\text { Hospital, Boston; Broad } \\
\text { Institute of MIT and } \\
\text { Harvard, Cambridge }\end{array}$ & Author & $\begin{array}{l}\text { Acquisition and } \\
\text { analysis of data }\end{array}$ \\
\hline $\begin{array}{l}\text { Andres } \\
\text { Ingason, PhD }\end{array}$ & $\begin{array}{l}\text { Mental Health Centre Sct } \\
\text { Hans, Roskilde, Denmark }\end{array}$ & Author & $\begin{array}{l}\text { Conception and } \\
\text { design of the } \\
\text { study and } \\
\text { acquisition and } \\
\text { analysis of data }\end{array}$ \\
\hline $\begin{array}{l}\text { Olafur B. } \\
\text { Davidsson, } \\
\text { MSc }\end{array}$ & $\begin{array}{l}\text { Rigshospitalet Glostrup, } \\
\text { Denmark }\end{array}$ & Author & $\begin{array}{l}\text { Acquisition and } \\
\text { analysis of data }\end{array}$ \\
\hline $\begin{array}{l}\text { Christian } \\
\text { Erikstrup, } \\
\text { PhD }\end{array}$ & $\begin{array}{l}\text { Department of Clinical } \\
\text { Immunology, Aarhus } \\
\text { University Hospital, } \\
\text { Denmark }\end{array}$ & Author & $\begin{array}{l}\text { Acquisition and } \\
\text { analysis of data }\end{array}$ \\
\hline $\begin{array}{l}\text { Henrik } \\
\text { Hjalgrim, PhD, } \\
\text { DMSc }\end{array}$ & $\begin{array}{l}\text { Department of Epidemiology } \\
\text { Research, Statens Serum } \\
\text { Institut, Copenhagen, } \\
\text { Denmark }\end{array}$ & Author & $\begin{array}{l}\text { Acquisition and } \\
\text { analysis of data }\end{array}$ \\
\hline $\begin{array}{l}\text { Henrik Ullum, } \\
\text { PhD }\end{array}$ & $\begin{array}{l}\text { Department of Clinical } \\
\text { Immunology, the Blood Bank, } \\
\text { Rigshospitalet, Copenhagen } \\
\text { University Hospital, } \\
\text { Denmark }\end{array}$ & Author & $\begin{array}{l}\text { Acquisition and } \\
\text { analysis of data }\end{array}$ \\
\hline $\begin{array}{l}\text { Jes Olesen, } \\
\text { DMSc }\end{array}$ & $\begin{array}{l}\text { Rigshospitalet Glostrup, } \\
\text { Denmark }\end{array}$ & Author & $\begin{array}{l}\text { Conception and } \\
\text { design of the } \\
\text { study; acquisition } \\
\text { and analysis of } \\
\text { data; and drafting } \\
\text { a significant } \\
\text { portion of the } \\
\text { manuscript or } \\
\text { figures }\end{array}$ \\
\hline $\begin{array}{l}\text { Thomas } \\
\text { Folkmann } \\
\text { Hansen, PhD }\end{array}$ & $\begin{array}{l}\text { Rigshospitalet Glostrup, } \\
\text { Denmark }\end{array}$ & Author & $\begin{array}{l}\text { Conception and } \\
\text { design of the } \\
\text { study; acquisition } \\
\text { and analysis of } \\
\text { data; and drafting } \\
\text { a significant } \\
\text { portion of the } \\
\text { manuscript or } \\
\text { figures }\end{array}$ \\
\hline
\end{tabular}

Appendix 2 Members of the DBDS Genomic Consortium (DBDS-GC)

\begin{tabular}{llll}
\hline Name & Location & Role & Contribution \\
\hline $\begin{array}{l}\text { Daniel } \\
\text { Gudbjartsson }\end{array}$ & $\begin{array}{l}\text { deCODE Genetics, } \\
\text { Reykjavik, Iceland }\end{array}$ & $\begin{array}{l}\text { Member } \\
\text { of the } \\
\text { DBDS-GC }\end{array}$ & $\begin{array}{l}\text { Acquisition of } \\
\text { data }\end{array}$ \\
\hline $\begin{array}{l}\text { Omar } \\
\text { Gastafsson }\end{array}$ & deCODE Genetics, & $\begin{array}{l}\text { Member } \\
\text { of the } \\
\text { Reykjavik, Iceland }\end{array}$ & $\begin{array}{l}\text { Acquisition of } \\
\text { data }\end{array}$ \\
& & DBDS-GC & \\
\hline
\end{tabular}

Continued 
Appendix 2 (continued)

\begin{tabular}{|c|c|c|c|}
\hline Name & Location & Role & Contribution \\
\hline $\begin{array}{l}\text { Kari } \\
\text { Stefansson }\end{array}$ & $\begin{array}{l}\text { deCODE Genetics, } \\
\text { Reykjavik, Iceland }\end{array}$ & $\begin{array}{l}\text { Member } \\
\text { of the } \\
\text { DBDS- } \\
\text { GC }\end{array}$ & $\begin{array}{l}\text { Acquisition of } \\
\text { data }\end{array}$ \\
\hline $\begin{array}{l}\text { Hreinn } \\
\text { Stefansson }\end{array}$ & $\begin{array}{l}\text { deCODE Genetics, } \\
\text { Reykjavik, Iceland }\end{array}$ & $\begin{array}{l}\text { Member } \\
\text { of the } \\
\text { DBDS- } \\
\text { GC }\end{array}$ & $\begin{array}{l}\text { Acquisition of } \\
\text { data }\end{array}$ \\
\hline $\begin{array}{l}\text { Unnur } \\
\text { Porsteinsdóttir }\end{array}$ & $\begin{array}{l}\text { deCODE Genetics, } \\
\text { Reykjavik, Iceland }\end{array}$ & $\begin{array}{l}\text { Member } \\
\text { of the } \\
\text { DBDS- } \\
\text { GC }\end{array}$ & $\begin{array}{l}\text { Acquisition of } \\
\text { data }\end{array}$ \\
\hline $\begin{array}{l}\text { Steffen } \\
\text { Andersen }\end{array}$ & $\begin{array}{l}\text { Department of Finance, } \\
\text { Copenhagen Business } \\
\text { School, Denmark }\end{array}$ & $\begin{array}{l}\text { Member } \\
\text { of the } \\
\text { DBDS- } \\
\text { GC }\end{array}$ & $\begin{array}{l}\text { Acquisition of } \\
\text { data }\end{array}$ \\
\hline Karina Banasik & $\begin{array}{l}\text { Novo Nordisk } \\
\text { Foundation Center for } \\
\text { Protein Research, } \\
\text { Faculty of Health and } \\
\text { Medical Sciences, } \\
\text { University of } \\
\text { Copenhagen, Denmark }\end{array}$ & $\begin{array}{l}\text { Member } \\
\text { of the } \\
\text { DBDS- } \\
\text { GC }\end{array}$ & $\begin{array}{l}\text { Acquisition of } \\
\text { data }\end{array}$ \\
\hline Søren Brunak & $\begin{array}{l}\text { Novo Nordisk } \\
\text { Foundation Center for } \\
\text { Protein Research, } \\
\text { Faculty of Health and } \\
\text { Medical Sciences, } \\
\text { University of } \\
\text { Copenhagen, Denmark }\end{array}$ & $\begin{array}{l}\text { Member } \\
\text { of the } \\
\text { DBDS- } \\
\text { GC }\end{array}$ & $\begin{array}{l}\text { Acquisition of } \\
\text { data }\end{array}$ \\
\hline Alfonso Buil & $\begin{array}{l}\text { Institute of Biological } \\
\text { Psychiatry, Mental } \\
\text { Health Centre Sct. Hans, } \\
\text { Copenhagen University } \\
\text { Hospital, Roskilde, } \\
\text { Denmark }\end{array}$ & $\begin{array}{l}\text { Member } \\
\text { of the } \\
\text { DBDS- } \\
\text { GC }\end{array}$ & $\begin{array}{l}\text { Acquisition of } \\
\text { data }\end{array}$ \\
\hline $\begin{array}{l}\text { Kristoffer } \\
\text { Burgdorf }\end{array}$ & $\begin{array}{l}\text { Department of Clinical } \\
\text { Immunology, the Blood } \\
\text { Bank, Rigshospitalet, } \\
\text { Copenhagen University } \\
\text { Hospital, Denmark }\end{array}$ & $\begin{array}{l}\text { Member } \\
\text { of the } \\
\text { DBDS- } \\
\text { GC }\end{array}$ & $\begin{array}{l}\text { Acquisition of } \\
\text { data }\end{array}$ \\
\hline $\begin{array}{l}\text { Christian } \\
\text { Erikstrup }\end{array}$ & $\begin{array}{l}\text { Department of Clinical } \\
\text { Immunology, Aarhus } \\
\text { University Hospital, } \\
\text { Denmark }\end{array}$ & $\begin{array}{l}\text { Member } \\
\text { of the } \\
\text { DBDS- } \\
\text { GC }\end{array}$ & $\begin{array}{l}\text { Acquisition of } \\
\text { data }\end{array}$ \\
\hline $\begin{array}{l}\text { Thomas } \\
\text { Folkmann } \\
\text { Hansen }\end{array}$ & $\begin{array}{l}\text { Danish Headache } \\
\text { Center, Department of } \\
\text { Neurology } \\
\text { Rigshospitalet, Glostrup } \\
\text { \& Institute of Biological } \\
\text { Psychiatry, Mental } \\
\text { Health Centre Sct. Hans, } \\
\text { Copenhagen University } \\
\text { Hospital, Roskilde, } \\
\text { Denmark }\end{array}$ & $\begin{array}{l}\text { Member } \\
\text { of the } \\
\text { DBDS- } \\
\text { GC }\end{array}$ & $\begin{array}{l}\text { Acquisition of } \\
\text { data }\end{array}$ \\
\hline $\begin{array}{l}\text { Henrik } \\
\text { Hjalgrim }\end{array}$ & $\begin{array}{l}\text { Department of } \\
\text { Epidemiology Research, } \\
\text { Statens Serum Institut, } \\
\text { Copenhagen, Denmark }\end{array}$ & $\begin{array}{l}\text { Member } \\
\text { of the } \\
\text { DBDS- } \\
\text { GC }\end{array}$ & $\begin{array}{l}\text { Acquisition of } \\
\text { data }\end{array}$ \\
\hline Jemec Gregor & $\begin{array}{l}\text { Department of Clinical } \\
\text { Medicine, Sealand } \\
\text { University Hospital, } \\
\text { Roskilde, Denmark }\end{array}$ & $\begin{array}{l}\text { Member } \\
\text { of the } \\
\text { DBDS- } \\
\text { GC }\end{array}$ & $\begin{array}{l}\text { Acquisition of } \\
\text { data }\end{array}$ \\
\hline
\end{tabular}

Appendix 2 (continued)

\begin{tabular}{|c|c|c|c|}
\hline Name & Location & Role & Contribution \\
\hline Poul Jennum & $\begin{array}{l}\text { Department of Clinical } \\
\text { Neurophysiology at } \\
\text { University of } \\
\text { Copenhagen, Denmark }\end{array}$ & $\begin{array}{l}\text { Member } \\
\text { of the } \\
\text { DBDS- } \\
\text { GC }\end{array}$ & $\begin{array}{l}\text { Acquisition of } \\
\text { data }\end{array}$ \\
\hline $\begin{array}{l}\text { Kasper Rene } \\
\text { Nielsen }\end{array}$ & $\begin{array}{l}\text { Department of Clinical } \\
\text { Immunology, Aalborg } \\
\text { University Hospital, } \\
\text { Denmark }\end{array}$ & $\begin{array}{l}\text { Member } \\
\text { of the } \\
\text { DBDS- } \\
\text { GC }\end{array}$ & $\begin{array}{l}\text { Acquisition of } \\
\text { data }\end{array}$ \\
\hline $\begin{array}{l}\text { Mette } \\
\text { Nyegaard }\end{array}$ & $\begin{array}{l}\text { Department of } \\
\text { Biomedicine, Aarhus } \\
\text { University, Denmark }\end{array}$ & $\begin{array}{l}\text { Member } \\
\text { of the } \\
\text { DBDS- } \\
\text { GC }\end{array}$ & $\begin{array}{l}\text { Acquisition of } \\
\text { data }\end{array}$ \\
\hline $\begin{array}{l}\text { Helene } \\
\text { Mariana } \\
\text { Paarup }\end{array}$ & $\begin{array}{l}\text { Department of Clinical } \\
\text { Immunology, Odense } \\
\text { University Hospital, } \\
\text { Denmark }\end{array}$ & $\begin{array}{l}\text { Member } \\
\text { of the } \\
\text { DBDS- } \\
\text { GC }\end{array}$ & $\begin{array}{l}\text { Acquisition of } \\
\text { data }\end{array}$ \\
\hline $\begin{array}{l}\text { Ole Birger } \\
\text { Pedersen }\end{array}$ & $\begin{array}{l}\text { Department of Clinical } \\
\text { Immunology, Naestved } \\
\text { Hospital }\end{array}$ & $\begin{array}{l}\text { Member } \\
\text { of the } \\
\text { DBDS- } \\
\text { GC }\end{array}$ & $\begin{array}{l}\text { Acquisition of } \\
\text { data }\end{array}$ \\
\hline Erik Sørensen & $\begin{array}{l}\text { Department of Clinical } \\
\text { Immunology, the Blood } \\
\text { Bank, Rigshospitalet, } \\
\text { Copenhagen University } \\
\text { Hospital, Denmark }\end{array}$ & $\begin{array}{l}\text { Member } \\
\text { of the } \\
\text { DBDS- } \\
\text { GC }\end{array}$ & $\begin{array}{l}\text { Acquisition of } \\
\text { data }\end{array}$ \\
\hline Henrik Ullum & $\begin{array}{l}\text { Department of Clinical } \\
\text { Immunology, the Blood } \\
\text { Bank, Rigshospitalet, } \\
\text { Copenhagen University } \\
\text { Hospital, Denmark }\end{array}$ & $\begin{array}{l}\text { Member } \\
\text { of the } \\
\text { DBDS- } \\
\text { GC }\end{array}$ & $\begin{array}{l}\text { Acquisition of } \\
\text { data }\end{array}$ \\
\hline Thomas Werge & $\begin{array}{l}\text { Institute of Biological } \\
\text { Psychiatry, Mental } \\
\text { Health Centre Sct. Hans, } \\
\text { Copenhagen University } \\
\text { Hospital, Roskilde, } \\
\text { Denmark \& Department } \\
\text { of Clinical Medicine, } \\
\text { University of } \\
\text { Copenhagen, Denmark }\end{array}$ & $\begin{array}{l}\text { Member } \\
\text { of the } \\
\text { DBDS- } \\
\text { GC }\end{array}$ & $\begin{array}{l}\text { Acquisition of } \\
\text { data }\end{array}$ \\
\hline
\end{tabular}

Appendix 3 Members of the International Headache Genetics Consortium (IHGC)

\begin{tabular}{llll}
\hline Name & Location & Role & Contribution \\
\hline $\begin{array}{l}\text { Verneri } \\
\text { Anttila }\end{array}$ & $\begin{array}{l}\text { Broad Institute of MIT } \\
\text { and Harvard, } \\
\text { Cambridge }\end{array}$ & $\begin{array}{l}\text { Member of } \\
\text { the IHGC }\end{array}$ & $\begin{array}{l}\text { Acquisition of } \\
\text { data }\end{array}$ \\
\hline Ville Artto & $\begin{array}{l}\text { Department of } \\
\text { Neurology, Helsinki } \\
\text { University Central } \\
\text { Hospital, Finland }\end{array}$ & $\begin{array}{l}\text { Member of } \\
\text { the IHGC }\end{array}$ & $\begin{array}{l}\text { Acquisition of } \\
\text { data }\end{array}$ \\
\hline $\begin{array}{l}\text { Andrea } \\
\text { Carmine } \\
\text { Belin }\end{array}$ & $\begin{array}{l}\text { Karolinska Institute, } \\
\text { Stockholm, Sweden }\end{array}$ & $\begin{array}{l}\text { Member of } \\
\text { the IHGC }\end{array}$ & $\begin{array}{l}\text { Acquisition of } \\
\text { data }\end{array}$ \\
\hline $\begin{array}{l}\text { Irene de Boer } \\
\text { Leiden University }\end{array}$ & $\begin{array}{l}\text { Member of } \\
\text { the IHGC }\end{array}$ & $\begin{array}{l}\text { Acquisition of } \\
\text { data }\end{array}$ \\
& $\begin{array}{l}\text { Nedical Centre, The } \\
\text { Netherlands }\end{array}$ & &
\end{tabular}


Appendix 3 (continued)

\begin{tabular}{|c|c|c|c|}
\hline Name & Location & Role & Contribution \\
\hline $\begin{array}{l}\text { Dorret I. } \\
\text { Boomsma }\end{array}$ & $\begin{array}{l}\text { VU University, } \\
\text { Amsterdam, The } \\
\text { Netherlands }\end{array}$ & $\begin{array}{l}\text { Member of } \\
\text { the IHGC }\end{array}$ & $\begin{array}{l}\text { Acquisition of } \\
\text { data }\end{array}$ \\
\hline Sigrid Børte & $\begin{array}{l}\text { Oslo University Hospital } \\
\text { and University of Oslo, } \\
\text { Norway }\end{array}$ & $\begin{array}{l}\text { Member of } \\
\text { the IHGC }\end{array}$ & $\begin{array}{l}\text { Acquisition of } \\
\text { data }\end{array}$ \\
\hline $\begin{array}{l}\text { Daniel I } \\
\text { Chasman }\end{array}$ & $\begin{array}{l}\text { Harvard Medical } \\
\text { School, Boston }\end{array}$ & $\begin{array}{l}\text { Member of } \\
\text { the IHGC }\end{array}$ & $\begin{array}{l}\text { Acquisition of } \\
\text { data }\end{array}$ \\
\hline Lynn Cherkas & $\begin{array}{l}\text { Department of Twin } \\
\text { Research and Genetic } \\
\text { Epidemiology, } \\
\text { King's College } \\
\text { London, UK }\end{array}$ & $\begin{array}{l}\text { Member of } \\
\text { the IHGC }\end{array}$ & $\begin{array}{l}\text { Acquisition of } \\
\text { data }\end{array}$ \\
\hline $\begin{array}{l}\text { Anne Francke } \\
\text { Christensen }\end{array}$ & $\begin{array}{l}\text { Danish Headache } \\
\text { Center, Department of } \\
\text { Neurology, } \\
\text { Rigshospitalet, } \\
\text { Glostrup Hospital, } \\
\text { University of } \\
\text { Copenhagen, Denmark }\end{array}$ & $\begin{array}{l}\text { Member of } \\
\text { the IHGC }\end{array}$ & $\begin{array}{l}\text { Acquisition of } \\
\text { data }\end{array}$ \\
\hline Bru Cormand & $\begin{array}{l}\text { University of Barcelona, } \\
\text { Spain }\end{array}$ & $\begin{array}{l}\text { Member of } \\
\text { the IHGC }\end{array}$ & $\begin{array}{l}\text { Acquisition of } \\
\text { data }\end{array}$ \\
\hline $\begin{array}{l}\text { Ester Cuenca- } \\
\text { Leon }\end{array}$ & $\begin{array}{l}\text { Broad Institute of MIT } \\
\text { and Harvard, } \\
\text { Cambridge }\end{array}$ & $\begin{array}{l}\text { Member of } \\
\text { the IHGC }\end{array}$ & $\begin{array}{l}\text { Acquisition of } \\
\text { data }\end{array}$ \\
\hline $\begin{array}{l}\text { George } \\
\text { Davey-Smith }\end{array}$ & $\begin{array}{l}\text { Medical Research } \\
\text { Council (MRC) } \\
\text { Integrative } \\
\text { Epidemiology Unit, } \\
\text { University of Bristol, UK }\end{array}$ & $\begin{array}{l}\text { Member of } \\
\text { the IHGC }\end{array}$ & $\begin{array}{l}\text { Acquisition of } \\
\text { data }\end{array}$ \\
\hline $\begin{array}{l}\text { Martin } \\
\text { Dichgans }\end{array}$ & $\begin{array}{l}\text { Institute for Stroke and } \\
\text { Dementia Research, } \\
\text { Munich, Germany }\end{array}$ & $\begin{array}{l}\text { Member of } \\
\text { the IHGC }\end{array}$ & $\begin{array}{l}\text { Acquisition of } \\
\text { data }\end{array}$ \\
\hline $\begin{array}{l}\text { Cornelia van } \\
\text { Duijn }\end{array}$ & $\begin{array}{l}\text { Erasmus University } \\
\text { Medical Centre, } \\
\text { Rotterdam, The } \\
\text { Netherlands }\end{array}$ & $\begin{array}{l}\text { Member of } \\
\text { the IHGC }\end{array}$ & $\begin{array}{l}\text { Acquisition of } \\
\text { data }\end{array}$ \\
\hline Tonu Esko & $\begin{array}{l}\text { Estonian Genome } \\
\text { Center, University of } \\
\text { Tartu, Estonia }\end{array}$ & $\begin{array}{l}\text { Member of } \\
\text { the IHGC }\end{array}$ & $\begin{array}{l}\text { Acquisition of } \\
\text { data }\end{array}$ \\
\hline $\begin{array}{l}\text { Ann-Louise } \\
\text { Esserlind }\end{array}$ & $\begin{array}{l}\text { Danish Headache } \\
\text { Center, Department of } \\
\text { Neurology, } \\
\text { Rigshospitalet, } \\
\text { Glostrup Hospital, } \\
\text { University of } \\
\text { Copenhagen, Denmark }\end{array}$ & $\begin{array}{l}\text { Member of } \\
\text { the IHGC }\end{array}$ & $\begin{array}{l}\text { Acquisition of } \\
\text { data }\end{array}$ \\
\hline $\begin{array}{l}\text { Michel } \\
\text { Ferrari }\end{array}$ & $\begin{array}{l}\text { Leiden University } \\
\text { Medical Centre, The } \\
\text { Netherlands }\end{array}$ & $\begin{array}{l}\text { Member of } \\
\text { the IHGC }\end{array}$ & $\begin{array}{l}\text { Acquisition of } \\
\text { data }\end{array}$ \\
\hline $\begin{array}{l}\text { Rune R. } \\
\text { Frants }\end{array}$ & $\begin{array}{l}\text { Leiden University } \\
\text { Medical Centre, The } \\
\text { Netherlands }\end{array}$ & $\begin{array}{l}\text { Member of } \\
\text { the IHGC }\end{array}$ & $\begin{array}{l}\text { Acquisition of } \\
\text { data }\end{array}$ \\
\hline $\begin{array}{l}\text { Tobias } \\
\text { Freilinger }\end{array}$ & $\begin{array}{l}\text { University of } \\
\text { Tuebingen, Germany }\end{array}$ & $\begin{array}{l}\text { Member of } \\
\text { the IHGC }\end{array}$ & $\begin{array}{l}\text { Acquisition of } \\
\text { data }\end{array}$ \\
\hline Nick Furlotte & $\begin{array}{l}\text { 23andMe Inc., } \\
\text { Mountain View }\end{array}$ & $\begin{array}{l}\text { Member of } \\
\text { the IHGC }\end{array}$ & $\begin{array}{l}\text { Acquisition of } \\
\text { data }\end{array}$ \\
\hline $\begin{array}{l}\text { Padhraig } \\
\text { Gormley }\end{array}$ & $\begin{array}{l}\text { Broad Institute of MIT } \\
\text { and Harvard, } \\
\text { Cambridge }\end{array}$ & $\begin{array}{l}\text { Member of } \\
\text { the IHGC }\end{array}$ & $\begin{array}{l}\text { Acquisition of } \\
\text { data }\end{array}$ \\
\hline
\end{tabular}

Appendix 3 (continued)

\begin{tabular}{|c|c|c|c|}
\hline Name & Location & Role & Contribution \\
\hline Lyn Griffiths & $\begin{array}{l}\text { Institute of Health and } \\
\text { Biomedical Innovation, } \\
\text { Queensland University } \\
\text { of Technology, } \\
\text { Brisbane, Australia }\end{array}$ & $\begin{array}{l}\text { Member of } \\
\text { the IHGC }\end{array}$ & $\begin{array}{l}\text { Acquisition of } \\
\text { data }\end{array}$ \\
\hline $\begin{array}{l}\text { Eija } \\
\text { Hamalainen }\end{array}$ & $\begin{array}{l}\text { Institute for Molecular } \\
\text { Medicine Finland } \\
\text { (FIMM), University of } \\
\text { Helsinki, Finland }\end{array}$ & $\begin{array}{l}\text { Member of } \\
\text { the IHGC }\end{array}$ & $\begin{array}{l}\text { Acquisition of } \\
\text { data }\end{array}$ \\
\hline $\begin{array}{l}\text { Thomas } \\
\text { Folkmann } \\
\text { Hansen }\end{array}$ & $\begin{array}{l}\text { Danish Headache } \\
\text { Center, Department } \\
\text { of Neurology, } \\
\text { Rigshospitalet, Glostrup } \\
\text { Hospital, University of } \\
\text { Copenhagen, Denmark }\end{array}$ & $\begin{array}{l}\text { Member of } \\
\text { the IHGC }\end{array}$ & $\begin{array}{l}\text { Acquisition of } \\
\text { data }\end{array}$ \\
\hline $\begin{array}{l}\text { Marjo } \\
\text { Hiekkala }\end{array}$ & $\begin{array}{l}\text { Folkhälsan Institute of } \\
\text { Genetics, Helsinki, } \\
\text { Finland }\end{array}$ & $\begin{array}{l}\text { Member of } \\
\text { the IHGC }\end{array}$ & $\begin{array}{l}\text { Acquisition of } \\
\text { data }\end{array}$ \\
\hline $\begin{array}{l}\text { M. Arfan } \\
\text { Ikram }\end{array}$ & $\begin{array}{l}\text { Erasmus University } \\
\text { Medical Centre, } \\
\text { Rotterdam, The } \\
\text { Netherlands }\end{array}$ & $\begin{array}{l}\text { Member of } \\
\text { the IHGC }\end{array}$ & $\begin{array}{l}\text { Acquisition of } \\
\text { data }\end{array}$ \\
\hline $\begin{array}{l}\text { Andres } \\
\text { Ingason }\end{array}$ & $\begin{array}{l}\text { deCODE Genetics Inc., } \\
\text { Reykjavik, Iceland }\end{array}$ & $\begin{array}{l}\text { Member of } \\
\text { the IHGC }\end{array}$ & $\begin{array}{l}\text { Acquisition of } \\
\text { data }\end{array}$ \\
\hline $\begin{array}{l}\text { Marjo-Riitta } \\
\text { Järvelin }\end{array}$ & $\begin{array}{l}\text { University of Oulu, } \\
\text { Biocenter, Finland }\end{array}$ & $\begin{array}{l}\text { Member of } \\
\text { the IHGC }\end{array}$ & $\begin{array}{l}\text { Acquisition of } \\
\text { data }\end{array}$ \\
\hline Risto Kajanne & $\begin{array}{l}\text { Institute for Molecular } \\
\text { Medicine Finland (FIMM), } \\
\text { University of Helsinki }\end{array}$ & $\begin{array}{l}\text { Member of } \\
\text { the IHGC }\end{array}$ & $\begin{array}{l}\text { Acquisition of } \\
\text { data }\end{array}$ \\
\hline Mikko Kallela & $\begin{array}{l}\text { Department of } \\
\text { Neurology, Helsinki } \\
\text { University Central } \\
\text { Hospital, Finland }\end{array}$ & $\begin{array}{l}\text { Member of } \\
\text { the IHGC }\end{array}$ & $\begin{array}{l}\text { Acquisition of } \\
\text { data }\end{array}$ \\
\hline Jaakko Kaprio & $\begin{array}{l}\text { Institute for Molecular } \\
\text { Medicine Finland } \\
\text { (FIMM), University of } \\
\text { Helsinki, Finland }\end{array}$ & $\begin{array}{l}\text { Member of } \\
\text { the IHGC }\end{array}$ & $\begin{array}{l}\text { Acquisition of } \\
\text { data }\end{array}$ \\
\hline $\begin{array}{l}\text { Mari } \\
\text { Kaunisto }\end{array}$ & $\begin{array}{l}\text { Folkhälsan Institute of } \\
\text { Genetics, Helsinki, } \\
\text { Finland }\end{array}$ & $\begin{array}{l}\text { Member of } \\
\text { the IHGC }\end{array}$ & $\begin{array}{l}\text { Acquisition of } \\
\text { data }\end{array}$ \\
\hline $\begin{array}{l}\text { Lisette J.A. } \\
\text { Kogelman }\end{array}$ & $\begin{array}{l}\text { Danish Headache } \\
\text { Center, Department of } \\
\text { Neurology, } \\
\text { Rigshospitalet, } \\
\text { Glostrup Hospital, } \\
\text { University of } \\
\text { Copenhagen, Denmark }\end{array}$ & $\begin{array}{l}\text { Member of } \\
\text { the IHGC }\end{array}$ & $\begin{array}{l}\text { Acquisition of } \\
\text { data }\end{array}$ \\
\hline $\begin{array}{l}\text { Christian } \\
\text { Kubisch }\end{array}$ & $\begin{array}{l}\text { University Medical } \\
\text { Center Hamburg- } \\
\text { Eppendorf, Germany }\end{array}$ & $\begin{array}{l}\text { Member of } \\
\text { the IHGC }\end{array}$ & $\begin{array}{l}\text { Acquisition of } \\
\text { data }\end{array}$ \\
\hline Mitja Kurki & $\begin{array}{l}\text { Broad Institute of MIT } \\
\text { and Harvard, } \\
\text { Cambridge }\end{array}$ & $\begin{array}{l}\text { Member of } \\
\text { the IHGC }\end{array}$ & $\begin{array}{l}\text { Acquisition of } \\
\text { data }\end{array}$ \\
\hline Tobias Kurth & $\begin{array}{l}\text { Harvard Medical } \\
\text { School, Boston }\end{array}$ & $\begin{array}{l}\text { Member of } \\
\text { the IHGC }\end{array}$ & $\begin{array}{l}\text { Acquisition of } \\
\text { data }\end{array}$ \\
\hline $\begin{array}{l}\text { Lenore } \\
\text { Launer }\end{array}$ & $\begin{array}{l}\text { National Institute on } \\
\text { Aging, Bethesda }\end{array}$ & $\begin{array}{l}\text { Member of } \\
\text { the IHGC }\end{array}$ & $\begin{array}{l}\text { Acquisition of } \\
\text { data }\end{array}$ \\
\hline $\begin{array}{l}\text { Terho } \\
\text { Lehtimaki }\end{array}$ & $\begin{array}{l}\text { School of Medicine, } \\
\text { Unviersity of } 3 \\
\text { Tampere, Finland }\end{array}$ & $\begin{array}{l}\text { Member of } \\
\text { the IHGC }\end{array}$ & $\begin{array}{l}\text { Acquisition of } \\
\text { data }\end{array}$ \\
\hline
\end{tabular}

Continued 
Appendix 3 (continued)

\begin{tabular}{|c|c|c|c|}
\hline Name & Location & Role & Contribution \\
\hline Davor Lessel & $\begin{array}{l}\text { University Medical } \\
\text { Center Hamburg- } \\
\text { Eppendorf, Germany }\end{array}$ & $\begin{array}{l}\text { Member of } \\
\text { the IHGC }\end{array}$ & $\begin{array}{l}\text { Acquisition of } \\
\text { data }\end{array}$ \\
\hline $\begin{array}{l}\text { Lannie } \\
\text { Ligthart }\end{array}$ & $\begin{array}{l}\text { VU University, } \\
\text { Amsterdam, The } \\
\text { Netherlands }\end{array}$ & $\begin{array}{l}\text { Member of } \\
\text { the IHGC }\end{array}$ & $\begin{array}{l}\text { Acquisition of } \\
\text { data }\end{array}$ \\
\hline $\begin{array}{l}\text { Nadia } \\
\text { Litterman }\end{array}$ & $\begin{array}{l}\text { 23andMe Inc., } \\
\text { Mountain View }\end{array}$ & $\begin{array}{l}\text { Member of } \\
\text { the IHGC }\end{array}$ & $\begin{array}{l}\text { Acquisition of } \\
\text { data }\end{array}$ \\
\hline $\begin{array}{l}\text { Arn van den } \\
\text { Maagdenberg }\end{array}$ & $\begin{array}{l}\text { Leiden University } \\
\text { Medical Centre, The } \\
\text { Netherlands }\end{array}$ & $\begin{array}{l}\text { Member of } \\
\text { the IHGC }\end{array}$ & $\begin{array}{l}\text { Acquisition of } \\
\text { data }\end{array}$ \\
\hline $\begin{array}{l}\text { Alfons } \\
\text { Macaya }\end{array}$ & $\begin{array}{l}\text { Vall d'Hebron Research } \\
\text { Institute, Barcelona, } \\
\text { Spain }\end{array}$ & $\begin{array}{l}\text { Member of } \\
\text { the IHGC }\end{array}$ & $\begin{array}{l}\text { Acquisition of } \\
\text { data }\end{array}$ \\
\hline Rainer Malik & $\begin{array}{l}\text { Institute for Stroke and } \\
\text { Dementia Research, } \\
\text { Munich, Germany }\end{array}$ & $\begin{array}{l}\text { Member of } \\
\text { the IHGC }\end{array}$ & $\begin{array}{l}\text { Acquisition of } \\
\text { data }\end{array}$ \\
\hline $\begin{array}{l}\text { Massimo } \\
\text { Mangino }\end{array}$ & $\begin{array}{l}\text { Department of Twin } \\
\text { Research and Genetic } \\
\text { Epidemiology, King's } \\
\text { College London, UK }\end{array}$ & $\begin{array}{l}\text { Member of } \\
\text { the IHGC }\end{array}$ & $\begin{array}{l}\text { Acquisition of } \\
\text { data }\end{array}$ \\
\hline $\begin{array}{l}\text { George } \\
\text { McMahon }\end{array}$ & $\begin{array}{l}\text { Medical Research } \\
\text { Council (MRC) Integrative } \\
\text { Epidemiology Unit, } \\
\text { University of Bristol, UK }\end{array}$ & $\begin{array}{l}\text { Member of } \\
\text { the IHGC }\end{array}$ & $\begin{array}{l}\text { Acquisition of } \\
\text { data }\end{array}$ \\
\hline $\begin{array}{l}\text { Bertram } \\
\text { Muller- } \\
\text { Myhsok }\end{array}$ & $\begin{array}{l}\text { Max Planck Institute of } \\
\text { Psychiatry, Munich, } \\
\text { Germany }\end{array}$ & $\begin{array}{l}\text { Member of } \\
\text { the IHGC }\end{array}$ & $\begin{array}{l}\text { Acquisition of } \\
\text { data }\end{array}$ \\
\hline $\begin{array}{l}\text { Benjamin M. } \\
\text { Neale }\end{array}$ & $\begin{array}{l}\text { Broad Institute of MIT } \\
\text { and Harvard, } \\
\text { Cambridge }\end{array}$ & $\begin{array}{l}\text { Member of } \\
\text { the IHGC }\end{array}$ & $\begin{array}{l}\text { Acquisition of } \\
\text { data }\end{array}$ \\
\hline $\begin{array}{l}\text { Carrie } \\
\text { Northover }\end{array}$ & $\begin{array}{l}\text { 23andMe Inc., } \\
\text { Mountain View }\end{array}$ & $\begin{array}{l}\text { Member of } \\
\text { the IHGC }\end{array}$ & $\begin{array}{l}\text { Acquisition of } \\
\text { data }\end{array}$ \\
\hline $\begin{array}{l}\text { Dale R. } \\
\text { Nyholt }\end{array}$ & $\begin{array}{l}\text { Institute of Health and } \\
\text { Biomedical Innovation, } \\
\text { Queensland University } \\
\text { of Technology, } \\
\text { Brisbane, Australia }\end{array}$ & $\begin{array}{l}\text { Member of } \\
\text { the IHGC }\end{array}$ & $\begin{array}{l}\text { Acquisition of } \\
\text { data }\end{array}$ \\
\hline Jes Olesen & $\begin{array}{l}\text { Danish Headache } \\
\text { Center, Department of } \\
\text { Neurology, } \\
\text { Rigshospitalet, Glostrup } \\
\text { Hospital, University of } \\
\text { Copenhagen, Denmark }\end{array}$ & $\begin{array}{l}\text { Member of } \\
\text { the IHGC }\end{array}$ & $\begin{array}{l}\text { Acquisition of } \\
\text { data }\end{array}$ \\
\hline Aarno Palotie & $\begin{array}{l}\text { Broad Institute of MIT } \\
\text { and Harvard, } \\
\text { Cambridge }\end{array}$ & $\begin{array}{l}\text { Member of } \\
\text { the IHGC }\end{array}$ & $\begin{array}{l}\text { Acquisition of } \\
\text { data }\end{array}$ \\
\hline Priit Palta & $\begin{array}{l}\text { Institute for Molecular } \\
\text { Medicine Finland } \\
\text { (FIMM), University of } \\
\text { Helsinki, Finland }\end{array}$ & $\begin{array}{l}\text { Member of } \\
\text { the IHGC }\end{array}$ & $\begin{array}{l}\text { Acquisition of } \\
\text { data }\end{array}$ \\
\hline $\begin{array}{l}\text { Linda } \\
\text { Pedersen }\end{array}$ & $\begin{array}{l}\text { Oslo University Hospital } \\
\text { and University of Oslo, } \\
\text { Norway }\end{array}$ & $\begin{array}{l}\text { Member of } \\
\text { the IHGC }\end{array}$ & $\begin{array}{l}\text { Acquisition of } \\
\text { data }\end{array}$ \\
\hline $\begin{array}{l}\text { Nancy } \\
\text { Pedersen }\end{array}$ & $\begin{array}{l}\text { Karolinska Institutet, } \\
\text { Stockholm, Sweden }\end{array}$ & $\begin{array}{l}\text { Member of } \\
\text { the IHGC }\end{array}$ & $\begin{array}{l}\text { Acquisition of } \\
\text { data }\end{array}$ \\
\hline $\begin{array}{l}\text { Danielle } \\
\text { Posthuma }\end{array}$ & $\begin{array}{l}\text { VU University, } \\
\text { Amsterdam, The } \\
\text { Netherlands }\end{array}$ & $\begin{array}{l}\text { Member of } \\
\text { the IHGC }\end{array}$ & $\begin{array}{l}\text { Acquisition of } \\
\text { data }\end{array}$ \\
\hline
\end{tabular}

Appendix 3 (continued)

\begin{tabular}{|c|c|c|c|}
\hline Name & Location & Role & Contribution \\
\hline $\begin{array}{l}\text { Patricia Pozo- } \\
\text { Rosich }\end{array}$ & $\begin{array}{l}\text { Headache Research } \\
\text { Group, Vall d'Hebron } \\
\text { Research Institute, } \\
\text { Universitat Autònoma } \\
\text { de Barcelona, Spain \& } \\
\text { Headache Unit, } \\
\text { Neurology Department, } \\
\text { Vall d'Hebron } \\
\text { University Hospital, } \\
\text { Barcelona, Spain }\end{array}$ & $\begin{array}{l}\text { Member of } \\
\text { the IHGC }\end{array}$ & $\begin{array}{l}\text { Acquisition of } \\
\text { data }\end{array}$ \\
\hline $\begin{array}{l}\text { Alice } \\
\text { Pressman }\end{array}$ & $\begin{array}{l}\text { Sutter Health, } \\
\text { Sacramento }\end{array}$ & $\begin{array}{l}\text { Member of } \\
\text { the IHGC }\end{array}$ & $\begin{array}{l}\text { Acquisition of } \\
\text { data }\end{array}$ \\
\hline Olli Raitakari & $\begin{array}{l}\text { Department of } \\
\text { Medicine, University of } \\
\text { Turku, Finland }\end{array}$ & $\begin{array}{l}\text { Member of } \\
\text { the IHGC }\end{array}$ & $\begin{array}{l}\text { Acquisition of } \\
\text { data }\end{array}$ \\
\hline $\begin{array}{l}\text { Markus } \\
\text { Schürks }\end{array}$ & $\begin{array}{l}\text { Harvard Medical } \\
\text { School, Boston }\end{array}$ & $\begin{array}{l}\text { Member of } \\
\text { the IHGC }\end{array}$ & $\begin{array}{l}\text { Acquisition of } \\
\text { data }\end{array}$ \\
\hline Celia Sintas & $\begin{array}{l}\text { University of Barcelona, } \\
\text { Spain }\end{array}$ & $\begin{array}{l}\text { Member of } \\
\text { the IHGC }\end{array}$ & $\begin{array}{l}\text { Acquisition of } \\
\text { data }\end{array}$ \\
\hline $\begin{array}{l}\text { Kari } \\
\text { Stefansson }\end{array}$ & $\begin{array}{l}\text { deCODE Genetics Inc., } \\
\text { Reykjavik, Iceland }\end{array}$ & $\begin{array}{l}\text { Member of } \\
\text { the IHGC }\end{array}$ & $\begin{array}{l}\text { Acquisition of } \\
\text { data }\end{array}$ \\
\hline $\begin{array}{l}\text { Hreinn } \\
\text { Stefansson }\end{array}$ & $\begin{array}{l}\text { deCODE Genetics Inc., } \\
\text { Reykjavik, Iceland }\end{array}$ & $\begin{array}{l}\text { Member of } \\
\text { the IHGC }\end{array}$ & $\begin{array}{l}\text { Acquisition of } \\
\text { data }\end{array}$ \\
\hline $\begin{array}{l}\text { Stacy } \\
\text { Steinberg }\end{array}$ & $\begin{array}{l}\text { deCODE Genetics Inc., } \\
\text { Reykjavik, Iceland }\end{array}$ & $\begin{array}{l}\text { Member of } \\
\text { the IHGC }\end{array}$ & $\begin{array}{l}\text { Acquisition of } \\
\text { data }\end{array}$ \\
\hline $\begin{array}{l}\text { David } \\
\text { Strachan }\end{array}$ & $\begin{array}{l}\text { Population Health } \\
\text { Research Institute, St } \\
\text { George's, University of } \\
\text { London, Cranmer } \\
\text { Terrace, London, UK }\end{array}$ & $\begin{array}{l}\text { Member of } \\
\text { the IHGC }\end{array}$ & $\begin{array}{l}\text { Acquisition of } \\
\text { data }\end{array}$ \\
\hline $\begin{array}{l}\text { Gisela } \\
\text { Terwindt }\end{array}$ & $\begin{array}{l}\text { Leiden University } \\
\text { Medical Centre, The } \\
\text { Netherlands }\end{array}$ & $\begin{array}{l}\text { Member of } \\
\text { the IHGC }\end{array}$ & $\begin{array}{l}\text { Acquisition of } \\
\text { data }\end{array}$ \\
\hline $\begin{array}{l}\text { Marta Vila- } \\
\text { Pueyo }\end{array}$ & $\begin{array}{l}\text { Vall d'Hebron Research } \\
\text { Institute, Barcelona, } \\
\text { Spain }\end{array}$ & $\begin{array}{l}\text { Member of } \\
\text { the IHGC }\end{array}$ & $\begin{array}{l}\text { Acquisition of } \\
\text { data }\end{array}$ \\
\hline $\begin{array}{l}\text { Maija } \\
\text { Wessman }\end{array}$ & $\begin{array}{l}\text { Folkhälsan Institute of } \\
\text { Genetics, Helsinki, } \\
\text { Finland }\end{array}$ & $\begin{array}{l}\text { Member of } \\
\text { the IHGC }\end{array}$ & $\begin{array}{l}\text { Acquisition of } \\
\text { data }\end{array}$ \\
\hline $\begin{array}{l}\text { Bendik S. } \\
\text { Winsvold }\end{array}$ & $\begin{array}{l}\text { Oslo University Hospital } \\
\text { and University of Oslo, } \\
\text { Norway }\end{array}$ & $\begin{array}{l}\text { Member of } \\
\text { the IHGC }\end{array}$ & $\begin{array}{l}\text { Acquisition of } \\
\text { data }\end{array}$ \\
\hline Huiying Zhao & $\begin{array}{l}\text { Institute of Health and } \\
\text { Biomedical Innovation, } \\
\text { Queensland University } \\
\text { of Technology, } \\
\text { Brisbane, Australia }\end{array}$ & $\begin{array}{l}\text { Member of } \\
\text { the IHGC }\end{array}$ & $\begin{array}{l}\text { Acquisition of } \\
\text { data }\end{array}$ \\
\hline $\begin{array}{l}\text { John-Anker } \\
\text { Zwart }\end{array}$ & $\begin{array}{l}\text { Oslo University Hospital } \\
\text { and University of Oslo, } \\
\text { Norway }\end{array}$ & $\begin{array}{l}\text { Member of } \\
\text { the IHGC }\end{array}$ & $\begin{array}{l}\text { Acquisition of } \\
\text { data }\end{array}$ \\
\hline
\end{tabular}

\section{References}

1. Endo A. The discovery and development of HMG-CoA reductase inhibitors. J Lipid Res 1992;33:1569-1582.

2. Kobylecki CJ, Jakobsen KD, Hansen T, Jakobsen IV, Rasmussen HB, Werge T. CYP2D6 genotype predicts antipsychotic side effects in schizophrenia inpatients: a retrospective matched case-control study. Neuropsychobiology 2009; 59:222-226.

3. Lewis CM, Vassos E. Prospects for using risk scores in polygenic medicine. Genome Med 2017;9:96. 
4. Glahn DC, McIntosh AM. Using polygenic risk scores to establish endophenotypes: considerations and current constraints. Biol Psychiatry Cogn Neurosci Neuroimaging 2017;2:113-114.

5. International Consortium on Lithium Genetics; Amare AT, Schubert KO, Hou L, et al. Association of polygenic score for schizophrenia and HLA antigen and inflammation genes with response to lithium in bipolar affective disorder: a genomewide association study. JAMA Psychiatry 2018;75:65-74.

6. Wimberley T, Gasse C, Meier SM, Agerbo E, MacCabe JH, Horsdal HT. Polygenic risk score for schizophrenia and treatment-resistant schizophrenia. Schizophrenia Bull 2017;43:1064-1069.

7. Mulder EJ, Van Baal C, Gaist D, et al. Genetic and environmental influences on migraine: a twin study across six countries. Twin Res 2003;6:422-431.

8. Ziegler DK, Hur YM, Bouchard TJ Jr, Hassanein RS, Barter R. Migraine in twins raised together and apart. Headache 1998;38:417-422.

9. Russell $\mathrm{MB}$, Olesen J. Increased familial risk and evidence of genetic factor in migraine. BMJ 1995;311:541-544.

10. Mokdad AH, Forouzanfar MH, Daoud F, et al. Global burden of diseases, injuries, and risk factors for young people's health during 1990-2013: a systematic analysis for the Global Burden of Disease Study 2013. Lancet 2016;387:2383-2401.

11. Diener HC, Limmroth V. Advances in pharmacological treatment of migraine. Expert Opin Investig Drugs 2001;10:1831-1845.

12. Gormley P, Anttila V, Winsvold BS, et al. Meta-analysis of 375,000 individuals identifies 38 susceptibility loci for migraine. Nat Genet 2016;48:856-866.

13. Esserlind AL, Christensen AF, Steinberg $\mathrm{S}$, et al. The association between candidate migraine susceptibility loci and severe migraine phenotype in a clinical sample. Cephalalgia 2016;36:615-623.

14. Christensen AF, Esserlind AL, Werge T, Stefánsson H, Stefánsson K, Olesen J. The in fluence of genetic constitution on migraine drug responses. Cephalalgia 2016;36:624-639.

15. Silberstein SD, Olesen J, Bousser MG, et al. The International Classification of Headache Disorders, 2nd edition (ICHD-II) — revision of criteria for 8.2 medicationoveruse headache. Cephalalgia 2005;25:460-465.
16. Purcell S, Neale B, Todd-Brown K, et al. PLINK: a tool set for whole-genome association and population-based linkage analyses. Am J Hum Genet 2007;81: 559-575.

17. Pritchard JK, Stephens M, Donnelly P. Inference of population structure using multilocus genotype data. Genetics 2000;155:945-959.

18. Vilhjálmsson Bjarni J, Yang J, Finucane Hilary K, et al. Modeling linkage disequilibrium increases accuracy of polygenic risk scores. Am J Hum Genet 2015;97:576-592.

19. Robin X, Turck N, Hainard A, et al. pROC: an open-source package for R and S+ to analyze and compare ROC curves. BMC Bioinformatics 2011;12:77.

20. $\quad R$ [computer program]. Vienna, Austria: The R Foundation; 2018.

21. Hansen TF, Banasik K, Erikstrup C, et al. DBDS Genomic Cohort, a prospective and comprehensive resource for integrative and temporal analysis of genetic, environmental and lifestyle factors affecting health of blood donors. BMJ Open 2019;9: e028401.

22. Hansen TF, Chalmer MA, Haspang TM, Kogelman LJA, Olesen J. Predicting treatment response using pharmacy register in migraine. J Headache Pain 2019; 20:31.

23. Relling MV, Evans WE. Pharmacogenomics in the clinic. Nature 2015;526:343-350.

24. Lee JW, Aminkeng F, Bhavsar AP, et al. The emerging era of pharmacogenomics: current successes, future potential, and challenges.Clin Genet 2014;86:21-28.

25. GENDEP Investigators, MARS Investigators, Investigators SD. Common genetic variation and antidepressant efficacy in major depressive disorder: a metaanalysis of three genome-wide pharmacogenetic studies. Am J Psychiatry 2013; 170:207-217.

26. Frank J, Lang M, Witt SH, et al. Identification of increased genetic risk scores for schizophrenia in treatment-resistant patients. Mol Psychiatry 2015;20:150-151.

27. Gormley P, Kurki MI, Hiekkala ME, et al. Common variant burden contributes significantly to the familial aggregation of migraine in 1,589 families. Neuron 2018;98: 743-753.

28. Scordo MG, Spina E. Cytochrome P450 polymorphisms and response to antipsychotic therapy. Pharmacogenomics 2002;3:201-218. 


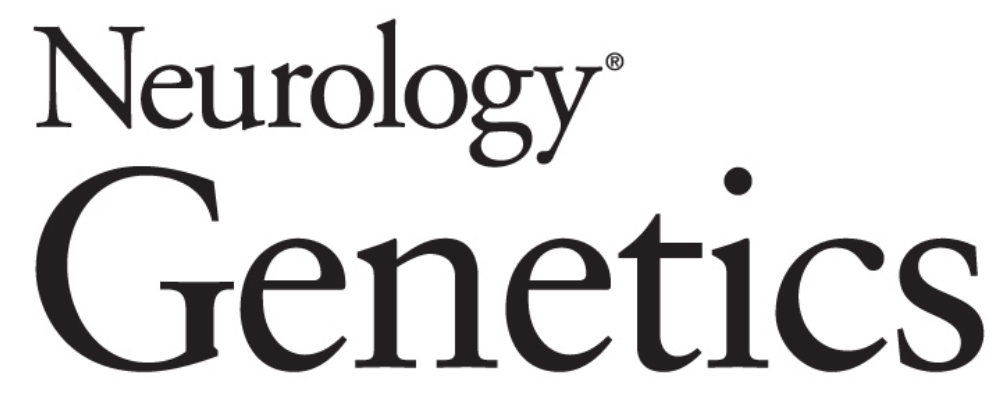

Migraine polygenic risk score associates with efficacy of migraine-specific drugs Lisette J.A. Kogelman, Ann-Louise Esserlind, Anne Francke Christensen, et al. Neurol Genet 2019;5;

DOI 10.1212/NXG.0000000000000364

This information is current as of October 24, 2019

$\begin{array}{ll}\begin{array}{l}\text { Updated Information \& } \\ \text { Services }\end{array} & \begin{array}{l}\text { including high resolution figures, can be found at: } \\ \text { http://ng.neurology.org/content/5/6/e364.full.html }\end{array} \\ \text { References } & \begin{array}{l}\text { This article cites } 27 \text { articles, } 2 \text { of which you can access for } \\ \text { http://ng.neurology.org/content/5/6/e364.full.html\#\#ref-lis }\end{array} \\ \text { This article has been cited by } 3 \text { HighWire-hosted articles: } \\ \text { http://ng.neurology.org/content/5/6/e364.full.html\#\#othe }\end{array}$

Neurol Genet is an official journal of the American Academy of Neurology. Published since April 2015, it is an open-access, online-only, continuous publication journal. Copyright Copyright @ 2019 The Author(s). Published by Wolters Kluwer Health, Inc. on behalf of the American Academy of Neurology.. All rights reserved. Online ISSN: 2376-7839.

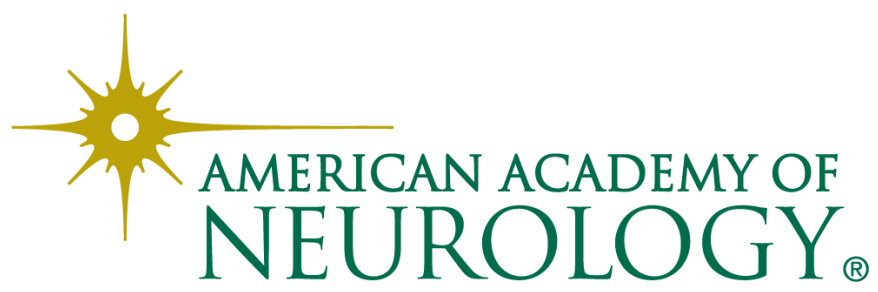

